\title{
THE INFLUENCE OF TRANSFORMATIONAL LEADERSHIP CHARACTERISTICS ON SUCCESSION PLANNING PROGRAMS IN THE MALAYSIAN PUBLIC SECTOR
}

\author{
Rohana Ahmad \\ School of Social and Economic Development \\ Universiti Malaysia Terengganu \\ rohana.a@umt.edu.my
}

Abstract: Grooming successful leaders is more important now than ever for the public sector. Thus, to groom potential future leaders, the organization not only needs a succession planning program, but also commitment from the leaders. This paper analyzes the influence of leadership style characteristics on preparing future leaders through succession planning programs in Malaysia's public sector. Four dimensions of transformational leadership styles were used which included idealized influence, inspirational motivation, individualized consideration, and intellectual stimulation. This study employed the Multifactor Leadership Questionnaire and the effective Succession Planning and Management Questionnaire which were administered to 394 public servants from Malaysia's public sector. Data was analyzed using multiple regression analysis. The results of the multiple regression analysis demonstrated that individualized influence was the main predictor of succession planning programs. Therefore, it is crucial for leaders to continue observing and modifying their leadership style(s) and behavior to be effective leaders.

Keywords: Public Sector, Leadership Characteristic Style, Succession Planning.

Abstrak: Penyediaan pemimpin yang berjaya adalah sangat penting pada masa sekarang dan juga akan datang dalam sektor awam. Oleh itu, untuk menyediakan pemimpin masa depan yang berpotensi, organisasi bukan sahaja memerlukan program perancangan penggantian, tetapi juga komitmen dari pemimpin. Sehubungan itu, kajian ini menganalisis pengaruh gaya kepimpinan kepimpinan dalam menyediakan pemimpin masa depan melalui program pelan penggantian di sektor Awam Malaysia. Empat 
dimensi gaya kepimpinan transformasi digunakan, termasuk pengaruh ideal, motivasi inspirasi, pengaruh individu, dan rangsangan intelektual. Kajian ini menggunakan soal selidik Pelbagai Faktor Kepemimpinan (MLQ) dan Perancangan dan Pengurusan Penggantian (SPMQ) yang berkesan yang diedarkan kepada 394 kakitangan awam dari Sektor Awam Malaysia. Data dianalisis dengan menggunakan analisis regresi berganda. Hasil dapatan analisis berganda menunjukkan bahawa pengaruh individu adalah prediktor utama dalam program perancangan penggantian. Oleh itu, sangat penting bagi semua pemimpin untuk terus melihat dan mengubah gaya dan tingkah laku kepimpinan mereka untuk menjadi pemimpin yang efektif.

Kata Kunci: Pentadbiran Awam Malaysia, Gaya kepemimpinan transformational, Pelan penggantian.

\section{INTRODUCTION}

The leader is the main pillar of human resource development in an organization. Immense leadership influence not only improves the performance of the organization, it also enhances the career development of its subordinates. There is a significant correlation between human resource management and organizational performance (Mesu, Sander \& Riemsdjik, 2015; Chia \& Zheng, 2015; Adnan \& Mubarak, 2010). This is also in line with the viewbased human resource function that has the potential to provide added value to the organization by enabling the development of its subordinates (Voon et al., 2011; Boselie et al., 2005).

The influence of leadership on subordinates is very significant in view of the relationship which occurs directly and formally. This influence can be seen from various aspects including training, motivation, performance evaluation and strategic staff planning. However, in succession planning, subordinates seem more significant because it is a medium to help shape future leaders as well as their career development. It is precisely at this time that leaders must have an effective leadership development strategy so that leaders in succession planning can be in form as required by the Public Service Department. 
A leader needs to be responsible for developing the organization and to use organizational resources optimally to reap the results of the development through strategic implementation. A leader is given the opportunity to lead, not because he/she is appointed by top management but because he/she is entrusted by followers to be a leader (Boseman, 2008). However, if the leader fails to deliver what is promised to the subordinates, he/she will lose their trust. Therefore, a leader should be focused on the needs of followers, both within and outside the organization to keep them moving forward on a consistent basis. Another key quality of a leader is to have vision. A leader who can anticipate the future will plan and include alternative strategies for the success of the organization.

The Malaysian public sector is the largest organization with employees totaling 1.6 million (PSD, 2015) personnel who make up the principal administrative machinery to ensure that the country is on track to achieve developed nation status by the year 2020 . The Public Service Department is aware of the importance of employing a strategic approach(s) in human resource management to improve the quality and productivity of the entire service. In order to strengthen the planning and governance of human resources, succession planning is a method that is extremely relevant to the process of preparing future leaders and for career development in an organization. The implementation of a proper succession process is also a distinguishing factor between an effective and an ineffective organization. Succession planning consists of the process of looking for a suitable potential candidate(s) as a future leader and for career development (Church \& Rotolo, 2013; Rothwel, 2010; Dessler, 2000). Therefore, the career paths of subordinates can be managed to fulfill organizational needs and also aspirations of the subordinates. Moreover, the implementation of succession planning on subordinates is closely linked to a leader's leadership style.

Research and literature on organizational leadership is relatively abundant (Abdulla, Ramadan \& Kamel, 2011). Indeed, there is overwhelming research evidence that leadership style has an important bearing on positive employee work outcomes such as job performance, job satisfaction, and organizational commitment (Ali et al., 2013). However, there are limited studies on aspects that examine the influence of leadership style on succession planning 
programs. Hence, this study intends to fill the gap by analyzing the influence of leadership style characteristics (idealized influence, inspirational motivation, individualized consideration, and intellectual stimulation) on succession planning programs (preparing for future leaders and career development) in the Malaysian public sector.

\section{THE ORETICAL BACKGROUND AND RESEARCH FRAMEWORK}

Theories relating to leadership are often of interest to academics as well as leaders of organizations in the private and public sectors. Reviews of work indicate that the concept of leadership has arisen and evolved into various phases, reflecting the changes in society, contemporary thinking and the treatment at the time. This is evidenced by the existence of the earliest leadership theory which is The Great Man Theory, which assumes that a leader is someone who has different features these days, the organization claimed to be more responsible for employees and greater transparency in action and decision making. Transformational leaders are leaders that encourage and inspire their subordinates through attractive vision (Bass \& Avolio, 1999; Bass \& Riggio, 2006). Burn (1978) defined transformational leadership as a relationship, mutual stimulation and elevations that convert followers into leaders and may convert leaders into moral agents. Studies have shown that transformational leadership is significantly positive with reference to organizational performance and effectiveness (Rusell, 2013; Sosik \& Jung, 2010; Avolio et al. 2009; Bass, 1998). In recent years, due to its influence on followers, leaders in the public sector have tried to adopt a transformational style in their approach to management. For instance, studies by Wang et al. (2011) in their meta-analytical review found that transformational leadership correlated positively with performance. According to Bass and Avolio (2004), transformational leadership displayed behaviors associated with the following four leadership styles:

Idealized influence is defined as the ability of leaders to serve as a model and show high performance and good ethics (Abdulla et al., 2011, Riaz \& Mubarak, 2010; Felfe et al., 2004). Consequently, 
leaders have specific characteristics or distinctive qualities. Idealized influence is in relation to an exemplary leader and trusted by his subordinates. These leaders strive to make decisions that benefit the organization. The effect of idealized influence is "faith, trust and replicable model disciple" (Stone, Russell \& Patterson, 2003; Simic, 1998). Confident subordinates and leaders facilitate changes to be constituted in an organization. Charisma is associated with leaders who inspire confidence (Gellis, 2001). A motivated leader is a leader who can motivate followers to achieve organizational goals (Russell, 2013; Ali et al., 2013). In fact, these leaders do not only motivate but also challenge their subordinates to strive for a higher standard; speak with enthusiasm and optimism, and give impetus and encouragement to do the things that will be done (Boyett, 2006). Encourage followers to be part of the organization (Boerner et al., 2007; Kelly, 2003).

Individualized consideration refers to the effort of the leaders to provide the human touch and holds subordinates through guidance and counseling for career growth. Subordinates are treated differently according to their individual abilities and knowledge (Rasid, 2007; Shin \& Zhou, 2003) giving a chance to followers to lead a better life (Junaida et al., 2011, Stone, Russell \& Patterson, 2003). Leaders who display individualized consideration are good listeners, advisers and charismatic coaches. In addition, to supporting the work done by subordinates, they practise two-way communication and distribute power to subordinates without prejudice (Walumbaw, 2008) and also drive organizations to achieve objectives.

Succession planning is a procedure that leads management to determine and address talent management schemes as they develop the organization, and people for the future (Rothwell, 2010; McCauley \& Wakefield, 2006). Succession planning is a critical process (Allan et al., 2015; Bjorkmen, 2013; LaForest \& Kubica, 2010; Beever, 2008) as well as a systematic method. Many researchers have introduced many models on succession planning, however one of the most popular models of succession planning was highlighted by Rothwell (2010). Rothwell (2010) stated that succession planning consisted of two dimensions: preparing for future leaders and career development. Preparing for future leaders is the key to ensuring that an organization maintains its ability to well-manage itself. Career 
development is an important strategy to facilitate internal promotion. Succession planning also describes management positions to offer extreme flexibility in lateral management moves. In order to secure that as individuals achieve greater seniority, their management skills will broaden and become more generalized in relation to total organizational objectives rather than purely departmental objectives. The important dimensions in succession planning are processes of preparing for future leaders and career development. Dessler (2004) likened succession planning as the process of looking for a likely chance for future leaders arising from firm strategic planning. Hence, subordinate career paths can be planned and properly executed to achieve organizational needs and fulfill subordinate aspirations. Some of the important processes to establish and attain effective career success include identifying potential nominees for the next leader (Amri, 2009; Rothwell, 2005; Dessler, 2004). Some of the most widely used interventions are career coaching, cross training and job enrichment and enlargement (Kirk et al., 2000).

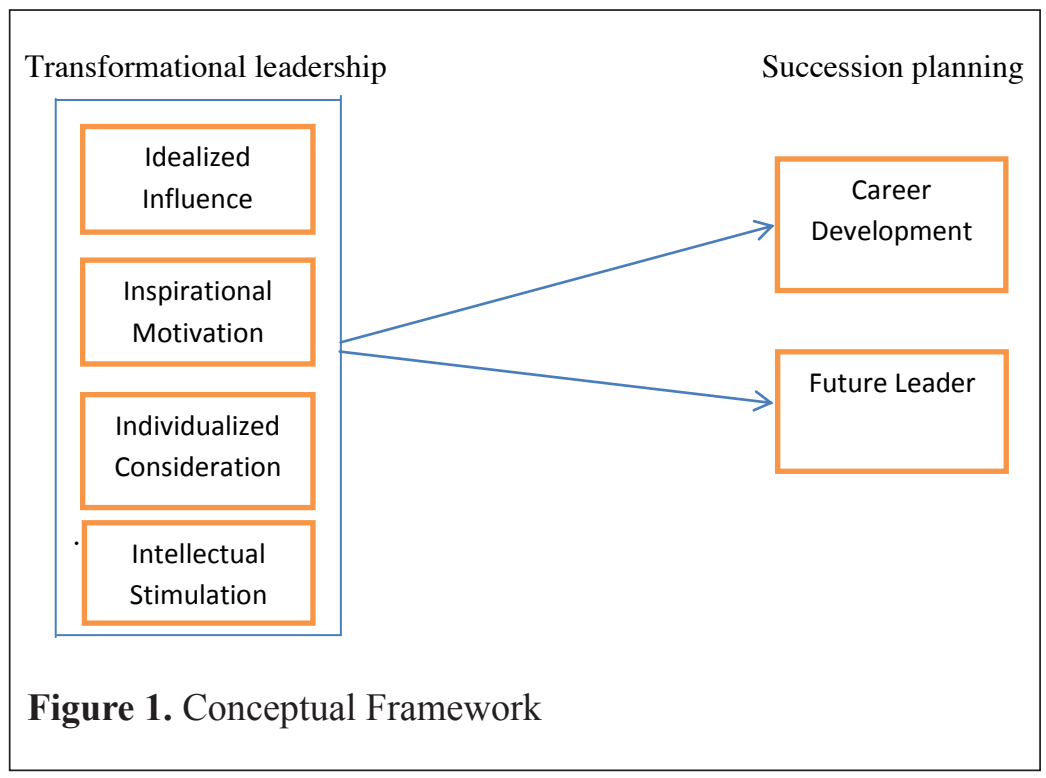

The success of transformational leadership style is manifold. Findings by Adnan and Mubarak (2010) revealed that transformational characteristics had strong associations with job success. Extensive research has been conducted on contemporary leadership 
characteristics and their impact on different constructs, however, significant contributions on succession planning contextualized in the Malaysian public sector have yet to be imparted. Therefore, this research is an attempt to determine the influence of transformational leadership on the implementation of succession planning programs in the Malaysian public sector. The conceptual framework as shown in Figure 1 for this research is an adaption from Bass and Avolio (2004). The transformational leadership components: idealized influence, inspirational motivation, individualized consideration and intellectual stimulation as independent variables. The succession planning component i.e. preparing for future leaders is the dependent variable.

\section{METHODOLOGY}

\section{Participants}

This research was conducted among subordinates from grade 48 to grade 54 in the Malaysian public sector. A sample of 576 respondents was selected using stratified random sampling, from 21 organizations to participate in the survey. A total of 576 questionnaires were distributed, 425 responded, 394 were found to be useful for statistical analysis. The response rate for this research was $68.4 \%$.

\section{Measures}

\section{Transformational Leadership and Succession Planning}

There were two variables to quantify in this research which were transformational leadership for the independent variable and succession planning for the dependent variable. The questionnaire consisted of three sections: demographic information, leadership dimensions and preparing for future leaders. Two sets of instruments were identified to measure the variables. To measure leadership style as perceived by the subordinates, the Multifactor Leadership Questionnaire (MLQ) based on a five-point Likert scale was used. The MLQ was designed and developed by Bass and Avolio (2004) and commonly used in leadership studies. The rating scale included: strongly disagree (1), disagree (2), neutral (3), agree (4) and strongly agree (5). The MLQ consisted of 20 items -8 items represented 
idealized influence, inspirational motivation ( 4 items), individualized consideration (4 items) and intellectual stimulation (4 items). This instrument has been used by researchers in many disciplines such as, education, marketing, private industries, the military and public sector in different countries (Abdul Rahman, 2009; Lowe et al, 1996; Antonakis et al, 2003; Bass and Avolio, 2004). Prior to maintaining the validity of the research, a pilot survey was carried out. The Cronbach's alpha value range from the pilot survey was between .714 and .890 which was acceptable (Hair et al., 1998) as shown in Table 1.

\section{Future Leaders and Career Development}

Instruments to measure preparing future leaders and career development were taken from the questionnaire for effective Succession Planning and Management (SP\&M) by Rothwell (2005). A total of 10 items represented preparing for future leaders and another 10 items for career development. A five-point Likert scale was utilized. The rating scale included: strongly disagree (1), disagree (2), neutral (3), agree (4) and strongly agree (5). The Cronbach's alpha value obtained was from 0.934 to 0.949 which was acceptable (Hair et al., 1998) as shown in Table 1.

Table 1. Cronbach's Alpha Coefficients

\begin{tabular}{lcc}
\hline Dimension & Item & Cronbach's alpha \\
Idealized influence & 8 & 0.890 \\
Inspirational motivation & 4 & 0.763 \\
Individualized consideration & 4 & 0.727 \\
Intellectual stimulation & 4 & 0.714 \\
Future leader & 10 & 0.949 \\
Career development & 10 & 0.934 \\
\hline
\end{tabular}

\section{FINDINGS}

\section{Descriptive Analysis}

The descriptive analysis in Table 2 reveals positive results for all variables. The highest calculated mean value of 4.02 for 
inspirational motivation showed that the subordinates felt that their supervisors always encouraged them to seek career satisfaction. An aggregate mean of 3.97 for intellectual stimulation explained the subordinates' perception oriented leadership style which allowed the subordinates to follow their career paths. The mean value of 3.84 for individualized consideration signified that the subordinates considered career success as related to leadership. The mean value for idealized influence was calculated at 3.64 which indicated the perception level of the subordinates toward the implementation of succession planning in the public sector.

In the multiple regression analysis, the dependent variable of succession planning was regressed against the independent variables. Multiple regression analysis was utilized to test the hypotheses of the relationships between the four dimensions of transformational leadership styles and grooming for future leadership. The results are summarized in Tables 3 and 4. The results showed that all four dimensions were positively related to preparing future leaders. The variables were inspirational motivation $(\beta=.133, p<0.05)$, individualized consideration $(\beta=.178, p<0.05)$ and intellectual

Table 2. Descriptive Analysis

\begin{tabular}{lcrrr}
\hline Dimension & Minimum & Maximum & Mean & $\begin{array}{c}\text { Standard } \\
\text { Deviation }\end{array}$ \\
& & & & \\
Idealized influence & 2.75 & 5.00 & 3.648 & .42249 \\
Inspirational motivation & 2.50 & 5.00 & 4.0281 & .50868 \\
Individualized & 2.25 & 5.00 & 3.8437 & .53215 \\
consideration & 2.75 & 5.00 & 3.9737 & .44634 \\
Intellectual stimulation & & & & \\
\hline
\end{tabular}

stimulation $(\beta=.128, p<0.05)$. While idealized influence was found to be not significant $(\beta=.067, p>0.05)$. These findings were consistent with previous research on leadership related to career outcomes (Mullen \& Kelloway, 2010; Xanthopoulou et al., 2008; Janneck, 2012). These determinations were also consonant with other researchers in other disciplines (Voon et al., 2011; Hinduan et al., 2009; Pattern, 1995) which found significant relationships between transformational leadership characteristics and job satisfaction. 
The results indicated that the correlation for all independent variables and dependent variables was moderate (R.435). It was also found that all the independent variables could explain $17.3 \%$ of the division in preparing future leaders. As shown in Table 3, the regression model was found to be fit $(\mathrm{F}=19.336$; $\mathrm{sig}=.000)$. The $\mathrm{R}^{2}$ indicated the coefficient of determination of the predictor variable on the dependent variable. As indicated in Table $3, \mathrm{R}^{2}$ showed a value of 18.9 that is $18.9 \%$ of the variance in succession planning, which means that the model fit is valid across different sample sizes and can be generalized to the study population. The strongest predictor can be seen by looking at the largest absolute beta value (Hair et al., 1998). As shown in Table 4, individualized influence showed the largest beta value of .178 , which was significant at .003 levels. This supports for that idealized influence variable influence most of the variance in preparing the future leader program perceived by subordinate. The finding provided full support for hypothesis H1. Therefore, this finding is consistent with Bass and Avolio (1999) who mentioned that transformational leaders are leaders who inspire their followers to work for their career paths.

Delegating authority to subordinates and fulfilling their needs are very important for leaders; moreover, they are continuously involved in the coaching process (Zaidatol Akmaliah et al., 2011; Northhouse, 2007; Reauvers et al., 2008). This finding supported previous research in Malaysia (Sadeghi \& Zaidatol Akmaliah, 2012; Lo et al., 2010). It can be concluded that followers rely on the leader to provide a better reference on making good use of work support for enhancing their career opportunities as well as preparing them to be future leaders. In addition, the positive impact of transformational leadership characteristics and relation support were found in this research to have exerted a strong influence on the subordinates' career paths. 
UUMJLS 9 July 2018 (39-56)

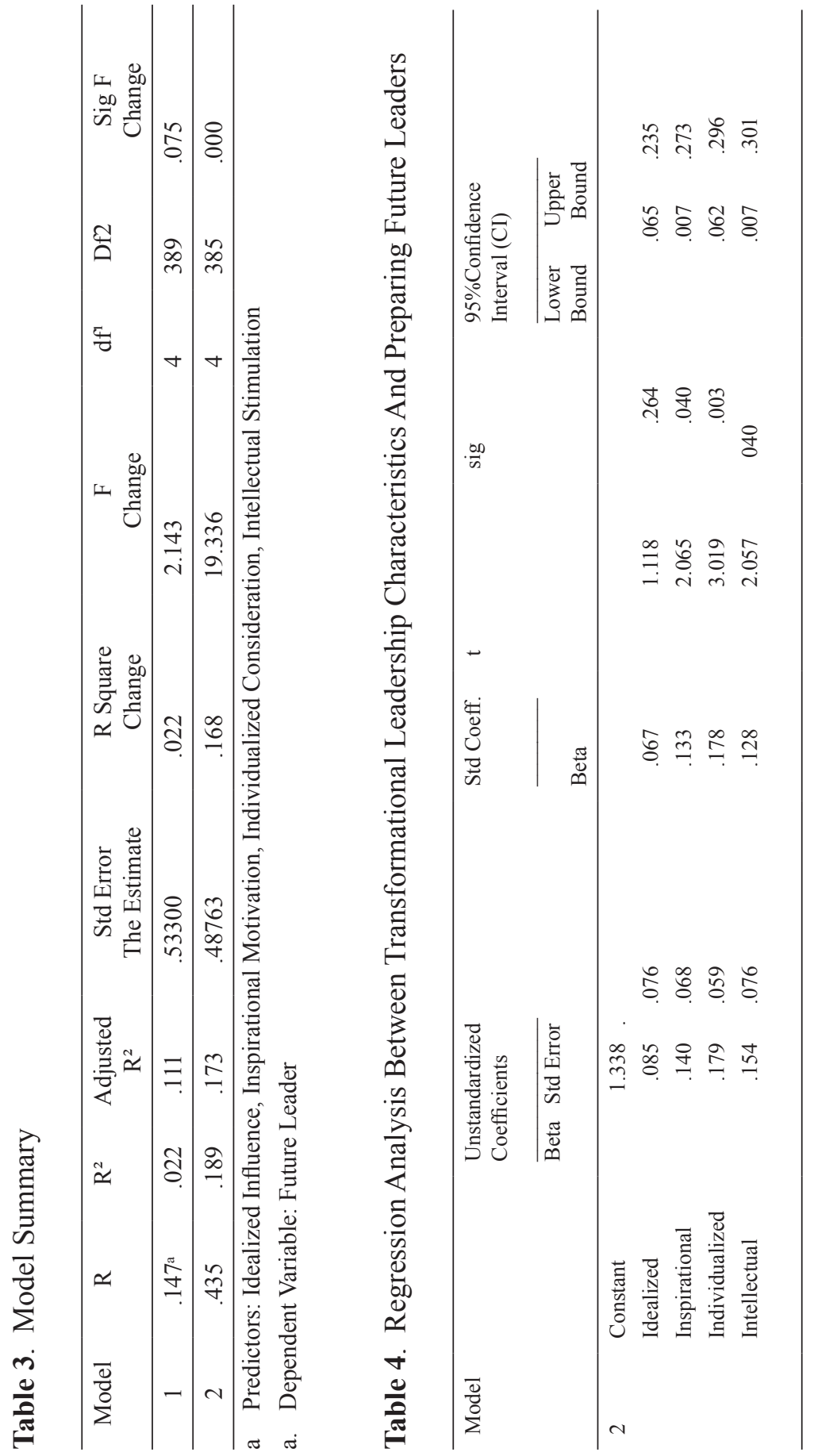




\section{DISCUSSION AND CONCLUSION}

A significant finding of the study revealed that succession planning programs are affected by leadership characteristics based on the perception of subordinates. With this in mind, the findings of this study has provided some practical insights on the need for the public sector to re-visit existing succession planning programs and leadership style(s) as these have significant bearing on followers' perception. Therefore, every organization must develop the capacity to manage unexpected changes at senior top management by developing a strong talent pipeline through matching skills available internally with higher level .... This is consistent with Spendlove (2007) who proposed that leadership development interventions need to begin far earlier in a career, so that success is built from bottom up, rather than top down. This was also significant with previous researchers who examined the relationship between transformational leadership and well-being (Kuoppala et al, 2008; Nielsen et al., 2008; Skakon et al., 2010). This analysis resonated well with the findings of studies engaged in the relationship between transformational leadership and subjective occupational success (Sylvie et al., 2012; Lasching et al., 2009; Llorens et al., 2006; Xanthopoulou et al., 2009). The recommendations offered here, should be understood from a social perspective whereby subordinates' behavioral and attitudinal responses and reactions are shaped by stimuli present in their work environment. In order to get appropriate responses from their subordinates, top management must take into consideration their work environment. Hence subordinates will respond accordingly when their contributions to secure better career paths are reciprocated.

Theoretically, this finding implies that preparing subordinates as future leaders shall be positively led by the charismatic individualized influence of transformational leadership. This outcome is in line with Floyd (2010), Lian and Tui, (2010), Ngang (2009), and Lowe et al. (1996). According to Bass (1990), a leader who shows clear vision and facilitates achievement will increase the perception of followers in the organization. These findings are consistent with other researches (Voon et al., 2011; Hinduan et al, 2009; Clabaugh, Monrao \& Sountar, 2000; Pattern, 1995). Nonetheless, such guidance can be effectively driven by strong support from the transformational leader. Based on the findings, the attribute of transformational 
leaders can be stretched to fit the work demands of highly in the career path. This is because employees could be a further request by the leader to give more willingness to act and support for the subordinate career establishment (Bass, 1998). The findings of this study is important and can be applied to Malaysia's Public Service Department in carrying out its succession planning programs and in promoting organizational effectiveness.

An effort to tap the intellectual capacity of the workforce requires leaders to have a strong definite sense of purpose, vision and strategic intent for the long term. At the same time, they need the ability to impart the sense of vision and purpose meaningfully to all in the organization. Much emphasis must be placed on getting across the dream and mission of the establishment and seeing to it that subordinates are empowered in carrying out their duties. Consequently, leadership characteristics need to be relevant for the enhancement of subordinates' career paths.

\section{REFERENCES}

Abdulla, J., Ramdane, D., \& Kamel, M. (2011). Determinations of job satisfaction in the UEA. Personnel Review, 40(1), $126-$ 146.

Abdul Rahman, A. (2009). Kepemimpinan transformasi: Kajian kes sistem penerbangan Malaysia. Pembentangan kertas kerja di kepimpinan politik dalam era perubahan dan krisis: Dilema dan cabaran masyarakat negara membangun.

Adnan, R. and Mubarak, H. H. (2010). Role of transformational and tractional leadership on job satisfaction and career satisfaction. Journal of Business and Economic Horizons, 1(1), 29-38.

Ali, Y., Ong, P. T., \& Elsadiq, M. A. (2013). Impact of the relationship behaviour transformational leadership and traditional leadership styles on Iran's automobile industry job satisfaction. Journal of Enterpreneurship, 9 (1), 14 -27.

Allan, H. C, Christopher, T. R, Nicole, M. G., \& Rebecca L. (2015). How are top companies designing and managing theirpotential programs? Consulting Psychology Journal, 67(1), $17-47$.

Antonakis, J., Avolio, B. J., \& Sivasubramaniam, N. (2003). Context and leadership: Examination of the nine-factor full- 
range leadership theory using the Multifactor Leadership Questionnaire. The Leadership Quarterly, 14(3), 261-295.

Avolio, B. J., \& Bass, B. M. (2004). Multifactor leadership questionnaire: Third edition manual and sampler set. Menlo Park, CA: Mind Garden, Inc.

Avolio, B. (1999). Full leadership development: Building the vital forces in organizations. Sage Publications, Thousand Oaks, CA.

Bass, B. M. (1990a). Bass and Stodgill's handbook of leadership: Theory, research and managerial implications (3rd ed.). New York: New York Press.

Bass, B. M. (1998). Transformational Leadership. Industrial, military and educational impact. LEA, Mahwah, NJ.

Bass, B. M., \& Avolio, B. J. (1999). Training full range leadership: A resource guide for training with the MLQ. Redwood City, CA: Mind Garden.

Bass, B. M., \& Riggio, R. E. (2006). Transformational leadership (2nd ed.). Mahwah, NJ: Lawrence Erlbaum Associates.

Beever, D. R. (2008). Integrating succession and career development strategies for finance professionals. (Diss, Canada Royal Roads University, 2008). Dissertation Abstracts International, Notre reference (ISBN: 978-0-494-44194-7).

Bjorkman, I., Ehrnrooth, M., Makela, K., Smale, A., \& Sumelius, J. (2013). Talent or not? Employee reactions to talent identification. Human Resource Management Journal, 52, 195-214.

Boselie, P.D. G., \& Boon, C. (2005). Commonalities and contradictions in HRM and performance research. Human Resources Management Journal, 16, 67-94.

Boseman, G. (2008). Effective leadership in a changing world. Journal of Financial Service Professionals, 62(3), 36 - 38.

Boyett, J. H. (2006). Transformational leadership: The highly effective leader/follower relationship. Retrieved from http:// www.jboyett.com

Burn, J. M. (1978). Leadership. New York: Harper and Row Publishers.

Boerner, S., Eisenbeiss, S., \& Griesser, D. (2007). Follower behavior and organizational performance: The impact of transformational leaders. Journal of Leadership \& Organizational Studies, 13(3), 15 - 36. 
Chua, Y. P. (2015). Kaedah dan statistik penyelidikan buku 5. Ujian regresi, analisis faktor dan analisis SEM, Kuala Lumpur: Mc Graw Hill Education (Malaysia) Sdn Bhd.

Church, A. H., \& Rotolo, C. T. (2013). How are top companies assessing their high-potentials and senior executives? A talent management benchmark study. Consulting Psychology Journal, 65, 199 -223.

Clabaugh, C. A., Monroe, G. S., \& Soutar, G. N. (2000). Supervisory factors affecting job satisfaction in public accounting firms. Australian Accounting Review. Vol. 10 (1), pp. 65 - 72.

Conger, J., \& Fulmer, R. (2003). Developing your leadership pipeline. Harvard Business Review. Vol. 3 (4) pp. 332 - 48.

Dessler, G. (2004). Management principles and practice for tomorrow's leader ( $\left.{ }^{\text {rd }} \mathrm{Ed}\right)$. Upper Saddle River, NJ: Pearson Education Inc.

Felfe, J., Tartler, K., \& Liepmann, D. (2004). Advanced research in the field of transformational leadership. German Journal of Human Resource Research, 18(3), 262-288.

Floyd, K. S. (2010). Leadership styles. ethics institutionalization. ethical work climate. and employee attitudes toward information technology misuse in higher education: A correlational study. (Unpublished doctoral dissertation), Statesboro, Georgia, USA.

Hair, J. F., Anderson, R. E., Tatham, R. L., \& William, C. (1998). Multivariate data analysis. Upper Saddle River, NJ: Prentice Hall.

Hinduan, Z. R., Wilson, E. E., Moss, S., \& Scannell, E. (2009). Leadership, work outcomes and openness to change following on Indonesian bank merger. Asia Pacific Journal of Human Resources, 47(1), 59 - 78 .

Janneck (2012). Transformational leadership, work engagement and occupational success. Journal of Career Development International. 17(7), $663-682$.

Junaida, I., Mahadir, L. A., \& Siti Hajar, M. A., (2011). Employee attitudes vs employee affective commitment. Global Journal of Human Social Science, 11(7), 77 - 79.

Kelly, M. L. (2003). Academic advisers as transformational leaders. The Mentor. Retrieve from http:/www.psu.edu/dus/ mentor/030101mk.htm

Kirk, J. J., Downey, B., Duckett, S., \& Woody, C. (2000). Name your career development intervention. Journal of Workplace Learning, 12(5), 205 -216 
Kuoppala, J., Lamminpaa, A., Liira, J., \& Vainio, H. (2008). Leadership, job well-being and health effects - a system review and a meta-analysis. Journal of Occupational and Environmental Medicine./American College of Occupational and Environmental Medicine, 50(8), 904 - 15.

LaForest, S., \& Kubica, T. (2010). Malaysia Tomorrow. Retrieved April 14, 2013, from Succession Planning: How to Meet Future Talent Needs: http://malaysia-tomorrow.com/successionplanning-how-to-meet-future-talent-needs/

Laschinger, H. K. S., Wilk, P., Cho. J., \& Greco, P. (2009). Empowerment, engagement and perceived effectiveness in nursing work environments: Does experience matter? Journal of Nursing Management, 17(5), 636 - 646.

Lian, L. K., \& Tui, L. G. (2012). Leadership styles and organizational citizenship behavior: The mediating effect of subordinates' competence and downward influence tactics. The Journal of Applied Business and Economics, 13(2), 59-96.

Lo, M. C., Ramayah, T., \& Cyril de Run. (2010). Does transformational leadership style foster commitment to change? The case of higher education in Malaysia. Procedia Social and Behavioural Sciences, 2, 5384 - 5388.

Lorents, S. B, A. B., Schaufeil, W., \& Salanova, M. (2006). Testing the robustness of the job demands-resources model. International Journal of Stress Management, 13(3), 378 - 391.

Lowe, K. B., Kroeck, K. G., \& Sivasubramaniam, N. (1996). Effectiveness correlates of transformational and transactional leadership: A meta-analytic review of the MLQ literature. Leadership Quarterly, 7, 385-425.

McCauley. C., \& Wakefield, M. (2006). Talent management in the 21st century: Help your company find, develop and keep its strongest workers. Journal for Quality \& Participate, 29, 4 -7 .

Muller, J., \& Kelloway, E. K. (2010). Occupational health and safety leadership. In quick, J. C. and Tetrick, L. E. (eds). Handbook of Occupational Health Psychology. 2nd ed. American Psychological Association, Washington, DC. pp. $357-72$.

Ngang, Tan Keow. (2009). Kepemimpinan transformasi guru besar dan ketegangan kerja guru. Jurnal Pengurusan dan Kepemimpinan Pendidikan, 19(1),107-121.

Nielsen, K., Randall. R., Yarker, J., \& Brenner, S. O. (2008). The 
effect of transformational leadership on followers' perceived work characteristics and psychological well-being: A longitudinal study. Work and Stress, 22(1), 16 - 32.

Northouse, P. (2007). Leadership theory and practice (4th ed.). Sage Publications.

Pattern, D. M. (1995). Supervisory actions and job satisfaction an analysis of differences between large and small public accounting firms. Accounting Horizons. 9(2), 328 -38.

Rasid, M. (2007). Kepemimpinan transformational: Konsep dan aplikasinya dalammemantapkan pengajaran dan pembelajaran. Universiti Teknologi MARA Pahang.

Reuvers, M., Van Engen, M. L., Vinkenburg, C., \& Wilson-Evered, E. (2008). Transformational leadership and innovative work behaviour. Exploring the relevance of gender differences. Creative and Innovative Management, 17, 227 - 44.

Riaz, A., \& Haider, M. (2010). Role of transformational and transactional leadership on job satisfaction and career satisfaction. Business and Economic Horizon, I(1), 29 - 38.

Rothwell, W. (2010). Effective succession planning, ensuring leadership continuity and building talent from within. 4th ed, American Management Association, New York.

Russell, P. G. (2013). The relationship between leader fit and transformational leadership. Journal of Managerial Psychology, 28(1), 55 - 73.

Sadeghi, A., \& Zaidatol Akhmaliah L.P. (2012). Transformational leadership and its predicted effects on leadership effectiveness. International Journal of Business and Social Science, 3(7), $186-197$.

Simic, I. (1998). Transformational leadership - the key to successful management of transformational organizational changes. Economic and Organizational Journal, 1, 45 - 49.

Skakon. J., Nielsen. K., Borg, V., \& Guzman, J. (2010). Are leaders' well-being, behaviors and style associated with the affective well-being of their employees? A systematic review of three decades of research. Work \& Stress, 24(2), 107-139.

Sosik, J. J., \& Jung, D. I. (2010). Full range leadership development: Pathways for people, profits, and planet. Routledge, New York, NY.

Spendlove, M. (2007). Competencies for effective leadership in higher education. International Journal of Educational Management, 21(5), 407 - 417.

Stone, A. G., Russell, R. F., \& Patterson, K. (2003). Transformational 
versus servant leadership: A difference in leadership focus. Servant leadership roundtable. Retrieve from http://www. regent.edu/acad/cls/2003servantleadershiprountable/stone/ pdf.

Syeda, S. G., \& Abida, D. (2014). Impact of Succession Planning on Employee Engagement in Telecommunication Sector in Rawalpindi, Pakistan. European Journal of Business and Management, 6(37), $274-281$.

Sylvie, H. V., Muser, C., Dan Hanneck, M., (2012).Transformational leadership, work engagement, and occupational success. Career Development International Journal, 17(7), 663 - 682.

Voon, M. L., Lo, M. C., Ngui, K. S., \& Ayob, N. B. (2011). The influence of leadership styles on employee job satisfaction in public sector organizations in Malaysia. International Journal of Business Management and Social Sciences, 2(1), 24 -32.

Wang, G., Oh, I., Courtright, S. H., \& Colbert, A. E. (2011). Transformational leadership and performance across criteria and levels: A meta-analytic review of 25 years of research. Group and Organization Management, 36(2), 223-270.

Walumbwa, F. O., Wang, P., Lawler, J., \& Shi, K. (2004). The role of collective efficacy in the relations between transformational leadership and work outcomes. Journal of Occupational and Organizational Psychology, 77, 515-530.

Xanthopoulou, D., Bakker, A. B., Heuven, E., Demerouti, E., \& Schaufeli, W.RB. (2009). Work enjoyment and financial returns: A diary study on the role of job and personal resources. Journal of Occupational and Organizational Psychology, 82 (1), $183-200$.

Zaidatol Akmalih, L. P., Sdeghi, A., \& Habibah E. (2011). Analysis of heads of department leadership styles: Implication for improving research university management practice. Procedia - Social and Behavioral Sciences, 29(2), 1081 - 1090. 